\title{
PERANCANGAN DAN PEMBUATAN XY-T RECODER BERBASIS DIGITAL DESIGN AND MANUFACTURE XY-T RECORDER BASED ON DIGITAL
}

\author{
Muchamad Gozali ${ }^{\text {a) }}$, Yudi Irawadi ${ }^{\text {b) }}$ \\ a),b) Balai Besar Teknologi Kekuatan Struktur - BPPTi \\ Kawasan PUSPIPTEK Gd. 220 Serpong, Tangerang 15314 \\ e-mail :gmuchamad@gmail.com, yudi irawadi@yahoo.com
}

Tanggal masuk naskah : 18/07/2014 ; Tanggal revisi: 19/09/2014 ; Tanggal persetujuan cetak : 08/10/2014

\begin{abstract}
Abstrak
$X Y-T$ Recorder adalah suatu alat ukur yang berfungsi untuk merekam data hasil uji statis yang ditampilkan dalam bentuk grafik. Grafik yang ditampilkan menunjukkan kondisi aktual dari besaran yang keluar dari sensor seperti loadcell (gaya), LVDT (defleksi), strain gauge (regangan) ataupun pressure (tekanan). Perancangan dan pembuatan $X Y-T$ Recorder berbasis digital ini bertujuan untuk memenuhi keterbatasan $X Y$-T Recorder analog yang dimiliki oleh B2TKS. Dari hasil kalibrasi menunjukkan ketidakpastian kalibrasi $0,13 \%$ pada tingkat kepercayaan $95 \%$ dengan faktor $\mathrm{k}=2$, hal ini menunjukkan ketelitian yang cukup bagus, dan dari hasil uji coba pada saat pengujian menunjukkan keluaran grafik dengan pola dan nilai besaran yang relatip sama dengan $X Y-T$ Recorder analog.
\end{abstract}

Kata Kunci : XY-T Recorder digital, Uji Statis, XY-T Recorder analog, Kalibrasi

\begin{abstract}
An $X Y$-T Recorder is a measuring equipment that function to record data of statical-testing result and it is shown in the form of graphs. The graphs of appearance indicate actual-condition of output censor such as Loadcell (Force), LVDT(deflection), Strain gauge (Strains) or Pressure. Design and manufacture of $X Y-T$ Recorder based in this digital is intended to satisfy the limit of $X Y-T$ Recorder analog available in B2TKS. The result of calibration shows certain calibration of $0.13 \%$ at the level trust of $95 \%$ with the factor $k=2$ and it indicates the accuracy to be fairly good. The result of experiment has displayed output of graphs with pattern and value magnitudes of relatively equal to the $X Y-T$ Recorder analog
\end{abstract}

Keywords : $X Y$-T Recorder digital, statical-testing, $X Y-T$ Recorder analog, Calibration

\section{PENDAHULUAN}

XY-T Recorder adalah suatu alat ukur yang berfungsi untuk merekam data hasil uj yang ditampilkan dalam bentuk grafik. Alat ini terdiri dari 2 (dua) bagian, yaitu untuk $X Y$ Recorder dan XT Recorder.

$X Y$ Recorder untuk merekam grafik dari hubungan antara dua sampai tiga keluaran dari sensor, pada kedua sumbu $X$ dan $Y$. Pada sumbu $Y$ umumnya berasal dari sensor Load Cell (gaya), sedangkan pada sumbu $X$ berasal dari sensor pressure (tekanan), strain gauge atau LVDT (defleksi).

XT Recorder untuk merekam grafik dari hubungan antara satu sampai dua keluaran dari sensor terhadap waktu (t). Pada sumbu $Y$ umumnya berasal dari sensor pressure (tekanan), strain gauge atau LVDT (defleksi), sedangkan untuk T dari waktu (t).

Alat ini sering digunakan pada uji statis seperti uji tiang pancang, uji komponen kendaraan, uji peralatan industri uji hidrostatis, dan lain-lain. 
Perancangan dan pembuatan $\mathrm{XY}-\mathrm{T}$ Recorder berbasis digital ini dilatar belakangi oleh keterbatasan XY-T Recorder analog yang dimiliki oleh B2TKS, pada saat perancangan dan pembuatan $\mathrm{XY}-\mathrm{T}$ Recorder berbasis digital ini, XY-T Recorder analog tinggal satu buah sisanya sudah rusak. Untuk memenuhi kebutuhan akan alat ini, maka penulis mencoba untuk melakukan perancangan dan pembuatan $\mathrm{XY}-\mathrm{T}$ Recorder berbasis digital, sehingga diharapkan dapat memenuhi kebutuhan XY$T$ Recorder pada pengujian-pengujian yang membutuhkan alat ini.

\section{BAHAN DAN METODA}

\subsection{Bahan}

Untuk merancang dan membuat alat ini diperlukan beberapa perangkat hardware, antara lain komputer jenis Laptop atau Notebook untuk menampilkan grafik hasil uji, ADC (Analog to Digital Converter) untuk mengkonversikan sinyal tegangan yang diperoleh dari amplifier menjadi sinyal digital, kabel konektor dari amplifier ke ADC dan Printer. Peralatan ini di-integerasikan dengan amplifier, control electronic dan peralatan ukur lainnya, sehingga menjadi suatu rangkaian sistem pengujian/ pengukuran.

\subsection{Metoda}

Untuk menyelesaikan perancangan dan pembuatan XY-T Recorder berbasis digital ini, metoda yang dilakukan adalah :
a. Perancangan konfigurasi
b. Perancangan software
c. Kalibrasi dan uji coba

Perancangan konfigurasi merupakan tahap awal dalam kegiatan ini, berisi perangkat (hardware) yang akan digunakan untuk mendukung sistem XY-T Recorder berbasis digital, sehingga menjadi satu kesatuan yang berfungsi dan menjadi suatu sistem.

Software dirancang mengikuti prosedur pengujian/pengukuran. Tahapan yang dilakukan adalah merancang menu, tampilan XY-T Recoder dan file output.

Tahap terakhir dilakukan kalibrasi dan uji coba. Kalibrasi dilakukan oleh laboratorium terakreditasi diluar B2TKS (independent) yaitu PT. Kaliman. Sedangkan uji coba dilakukan dengan cara membandingkan antara XY-T Recorder berbasis digital hasil rancangan dengan $\mathrm{XY}$ $\mathrm{T}$ Recorder berbasis analog yang telah dimiliki oleh B2TKS.

\section{HASIL DAN PEMBAHASAN}

XY-T Recorder merupakan salah satu bagian dari suatu sistem pengujian/ pengukuran yang membutuhkan alat perekam grafik yang menunjukkan keluaran dari sensor seperti Loadcell (gaya), LVDT (defleksi), Strain Gauge (regangan) ataupun Pressure (tekanan).

\subsection{Perancangan Konfigurasi}

XY-T Recorder berbasis digital ini dirancang memiliki 3 input kanal dengan range input tegangan yang dapat diterima adalah \pm 10 Volt. Untuk XT-Recorder memiliki 2 (dua) input kanal, disediakan untuk menerima 2 (dua) input yang akan ditampilkan pada sumbu $Y$, sedangkan untuk sumbu $X$ adalah waktu (t). Sedangkan untuk $\mathrm{XY}$-Recorder memiliki 3 (tiga) input kanal, disediakan untuk menerima 2 (dua) input yang akan ditampilkan pada sumbu $\mathrm{X}$, dan 1 (satu) input kanal yang akan ditampilkan pada sumbu $Y$. Hasil rancangan dan pembuatan $\mathrm{XY}-\mathrm{T}$ Recorder berbasis digital dapat dilihat pada gambar 1 .

Konfigurasi sistem pengujian dapat berbeda tergantung jenis pengujiannya. Gambar 2 menunjukkan konfigurasi pengujian hidrostatis dan gambar 3 menunjukkan konfigurasi pengujian statis.

Sistem pengujian hidrostatis terdiri dari pompa, valve, pressure transducer, amplifier, XY-T Recorder dan printer.

Sedangkan pengujian statis terdiri dari control electronic, actuator, loadcell, LVDT dan/atau strain gauge, amplifier, XY-T Recorder dan printer.

Pada pengujian hidrostatis pompa berfungsi untuk menghasilkan tekanan, valve atau katup berfungsi sebagai pengaman dan pengatur tekanan, pressure transducer berfungsi untuk mengukur tekanan yang terjadi akibat dari tekanan yang diberikan pompa, amplifier akan memperbesar nilai tegangan yang dihasilkan oleh pressure transducer dan menampilkannya ke layar berupa angka, kemudian amplifier dihubungkan ke XY-T Recorder untuk merekam dalam bentuk grafik.

Pada pengujian statis control electronic berfungsi sebagai pembangkit/ 
pengendali gaya (beban), berfungsi untuk menggerakkan actuator sehingga akan memberikan beban kepada benda uji. Loadcell berfungsi untuk mengukur gaya yang terjadi pada saat actuator bergerak menekan/menarik benda uji, LVDT berfungsi untuk mengukur besarnya defleksi (pergerakan benda uji dalam satuan $\mathrm{mm}$ ) pada saat benda uji diberikan beban oleh Control Electronic, strain gauge berfungsi untuk mengukur besarnya regangan yang terjadi pada benda uji. Amplifier akan memperbesar nilai tegangan yang dihasilkan oleh strain gauge, kemudian amplifier dihubungkan ke XY-T Recorder untuk merekam dalam bentuk grafik.

\subsection{Perancangan Software}

Software dibuat dengan bahasa pemrograman Visual Basic 6.0 (VB 6.0). VB 6.0 adalah bahasa pemrograman yang mudah dan memakai sistem GUI (Graphical User Interface). Tahap pertama adalah merancang menu, menu dibuat dibuat berdasarkan prosedur yang dibutuhkan atau tahapan yang akan dilakukan pada saat persiapan, mulai perekaman dan sesudah perekaman data/grafik.

Menu dibagi 2 (dua) bagian, yaitu menu utama dan sub menu. Menu utama terdiri dari Recorder, Report, Help dan Exit. Menu Recorder terdiri dari XT dan XY, sub menu XT untuk menampilkan window XT Recorder, dan sub menu $X Y$ untuk menampilkan window $X Y$ Recorder. Menu Report terdiri dari XT dan XY, sub menu XT untuk menampilkan window XT Report, dan sub menu $X Y$ untuk menampilkan window XY Report. Menu Help untuk menampilkan window Help atau bantuan, sedangkan menu Exit untuk keluar dari software.

Untuk memakai XT-Recorder pada menu utama pilih menu Recorder, lalu pilih $\mathrm{XT}$, maka akan tampil window XT-Recorder. Window XT-Recorder terdiri dari menu, frame grafik, judul, nilai maksimum/ minimum, comco-box dan kotak text-box yang harus dipilih dan harus diisi sebelum pengujian dimulai.

Pada window XT-Recorder, sebelum pengujian dimulai juga harus melakukan persiapan seperti memilih menu File Name untuk menyiapkan nama file data rekam hasil pengujian/pengukuran, memilih menu Title untuk mengisi judul pengujian yang akan ditampilkan pada layar. Pada XTRecorder disediakan 2 (dua) input kanal yang akan ditampilkan pada sumbu $Y$. Setting yang harus dilakukan adalah memilih sensor yang digunakan, unit, faktor (unit/volt), polarity (normal/invert), range maksimum keluaran. Setting untuk sumbu $X$ adalah memilih satuan waktu detik atau menit, serta range maksimum satuan waktu yang dipilih.

Untuk memakai XY-Recorder pada menu utama pilih menu Recorder, lalu pilih $X Y$, maka akan tampil window $X Y$-Recorder. Window XY-Recorder terdiri dari menu, frame grafik, judul, nilai maksimum/ minimum, comco-box dan kotak text-box yang harus dipilih dan harus diisi sebelum pengujian dimulai.

Pada window XY-Recorder, sebelum pengujian dimulai harus dilakukan persiapan seperti memilih menu File Name untuk menyiapkan nama file data rekam hasil pengujian/pengukuran, memilih menu Title untuk mengisi judul pengujian yang akan ditampilkan pada layar. Pada XY-Recorder disediakan 3 (tiga) input kanal, maka ada 3 (tiga) setting yang harus dilakukan, 1 (satu) input kanal untuk sumbu $Y$ dan 2 (dua) input kanal untuk sumbu $X$. Setting yang harus dilakukan adalah memilih sensor yang digunakan, unit, faktor (unit/volt), polarity (normal/invert), range maksimum keluaran.

Untuk memakai XT-Report pada menu utama pilih menu Report, lalu pilih XT, maka akan tampil window XT-Report. Window XT-Report terdiri dari menu, frame grafik, comco-box untuk seting atau merubah skala grafik, nilai maksimum/ minimum.

Untuk memakai XY-Report pada menu utama pilih menu Report, lalu pilih $X Y$, maka akan tampil window XY-Report. Window $X Y$-Report terdiri dari menu, frame grafik, comco-box untuk seting atau merubah skala grafik, nilai maksimum/ minimum.

Menu Help pada menu utama berfungsi untuk menampilkan keterangan tentang fungsi dari menu-menu yang ada pada menu utama.

Hasil rancangan menu utama window XT-Recorder, dan window XY-Recorder dapat dilihat pada Gambar 4, 5 dan 6 . Sedangkan setting window XT-Recorder dan window XY-Recorder pada saat pengujian ditunjukkan pada gambar 7 dan 8 .

\subsection{Kalibrasi dan Uji Coba}

\subsubsection{Kalibrasi}

Definisi kalibrasi menurut ISO/IEC Guide 17025:2005 dan Vocabulary of International Metrology (VIM) adalah 
serangkaian kegiatan yang membentuk hubungan antara nilai yang ditunjukkan oleh instrumen ukur atau sistem pengukuran, atau nilai yang diwakili oleh bahan ukur, dengan nilai-nilai yang sudah diketahui yang berkaitan dari besaran yang diukur dalam kondisi tertentu.

Dengan kata lain kalibrasi adalah kegiatan untuk menentukan kebenaran konvensional nilai penunjukkan alat ukur dan bahan ukur dengan cara membandingkan terhadap standar ukur yang mampu telusur (traceable) ke standar nasional maupun internasional untuk satuan ukuran dan/atau internasional dan bahanbahan acuan tersertifikasi.

Tujuan dilakukannya kalibrasi adalah : Untuk mencapai ketertelusuran pengukuran

1. Hasil pengukuran dapat dikaitkan/ ditelusur sampai ke standar yang lebih tinggi/teliti (standar primer nasional dan/ internasional), melalui rangkaian perbandingan yang tak terputus.

2. Menentukan deviasi (penyimpangan) kebenaran nilai konvensional penunjukan suatu instrument ukur.

3. Menjamin hasil-hasil pengukuran sesuai dengan standar Nasional maupun Internasional.

Salah satu persyaratan kalibrasi adalah dilakukan dan dibuktikan dengan sertifikasi dari laboratorium yang terakreditasi, dan XY-T Recorder berbasis digital telah dilakukan kalibrasi oleh PT. Kaliman.

Gambar 9 dan 10 menunjukkan sertifikat hasil kalibrasi yang telah dilakukan oleh PT. Kaliman.

Dari hasil kalibrasi menunjukkan, $\mathrm{XY}$ $\mathrm{T}$ Recorder berbasis digital memiliki ketidakpastian kalibrasi sebesar $0,13 \%$.
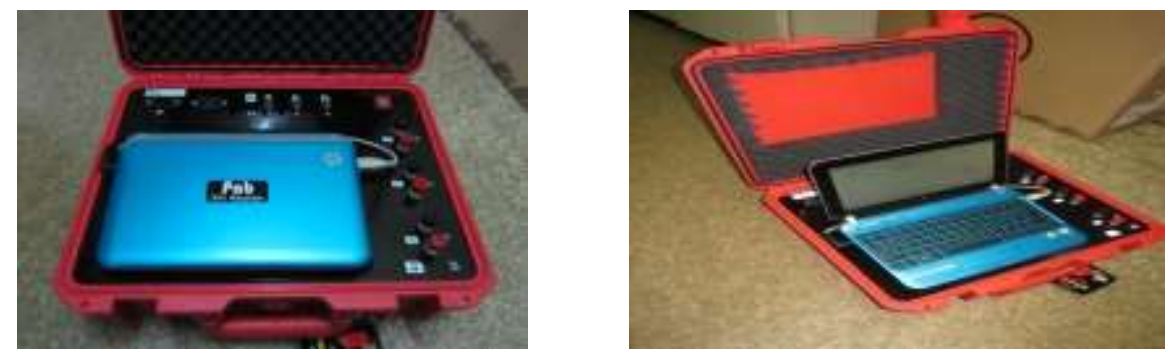

Gambar 1 : Hasil rancangan dan pembuatan XY-T Recorder berbasis digital

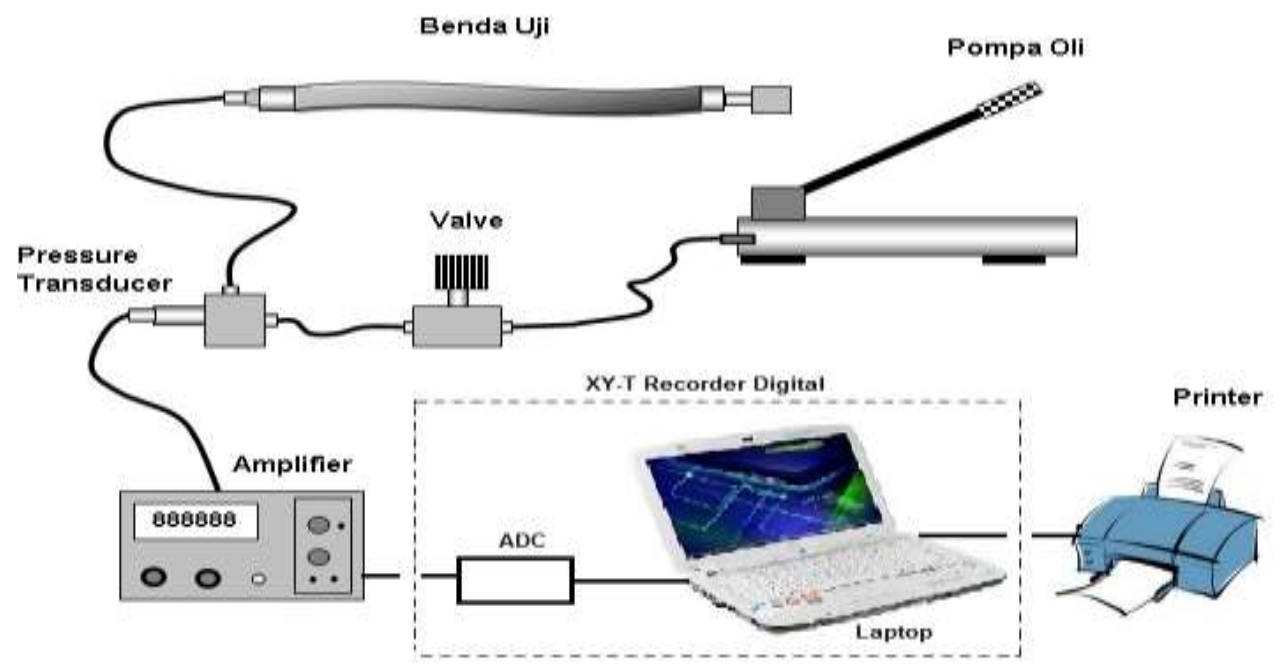

Gambar 2 : Konfigurasi sistem pengujian hidrostatis 


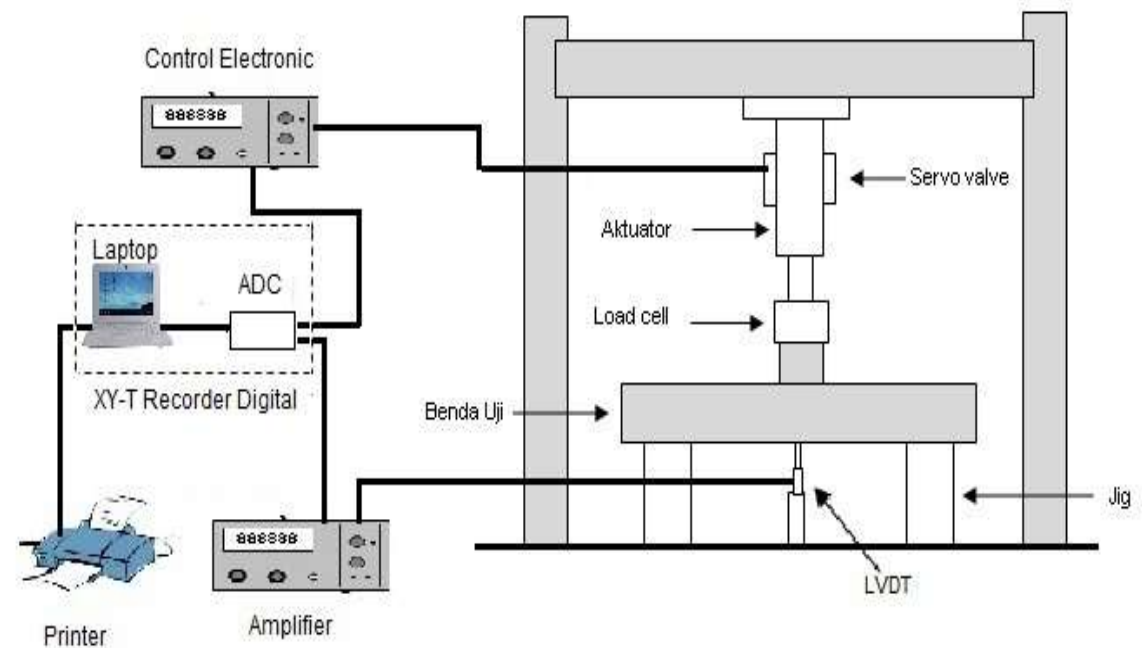

Gambar 3 : Konfigurasi sistem pengujian statis

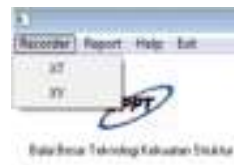

Digital XT / XY Recorder

Gambar 4 : Rancangan menu utama

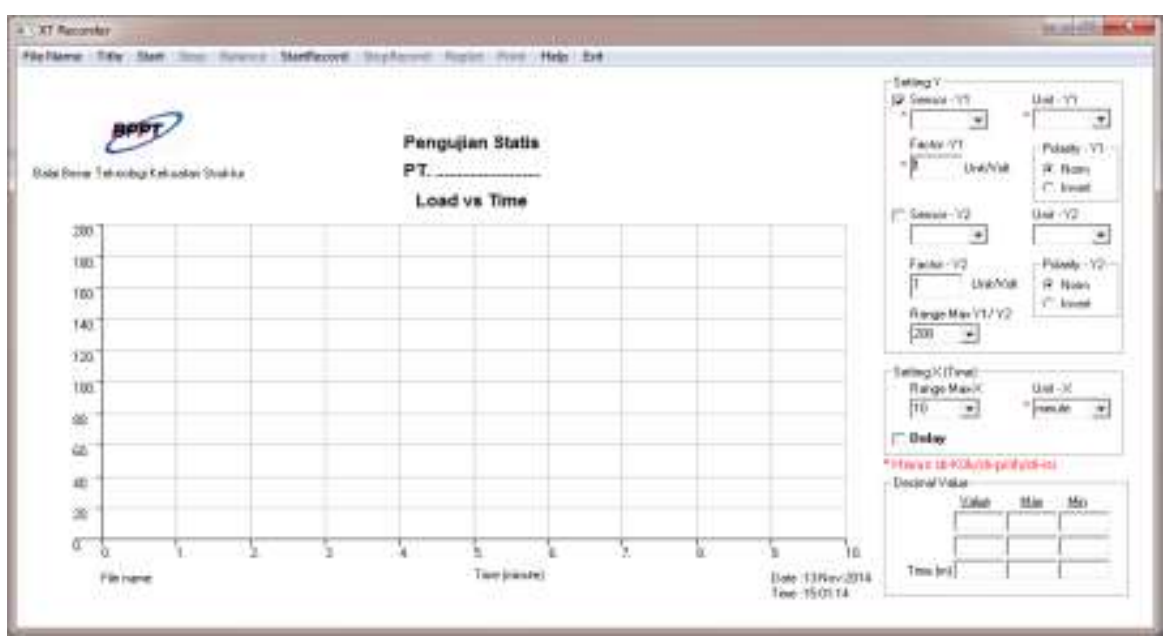

Gambar 5 : Rancangan window XT Recorder 


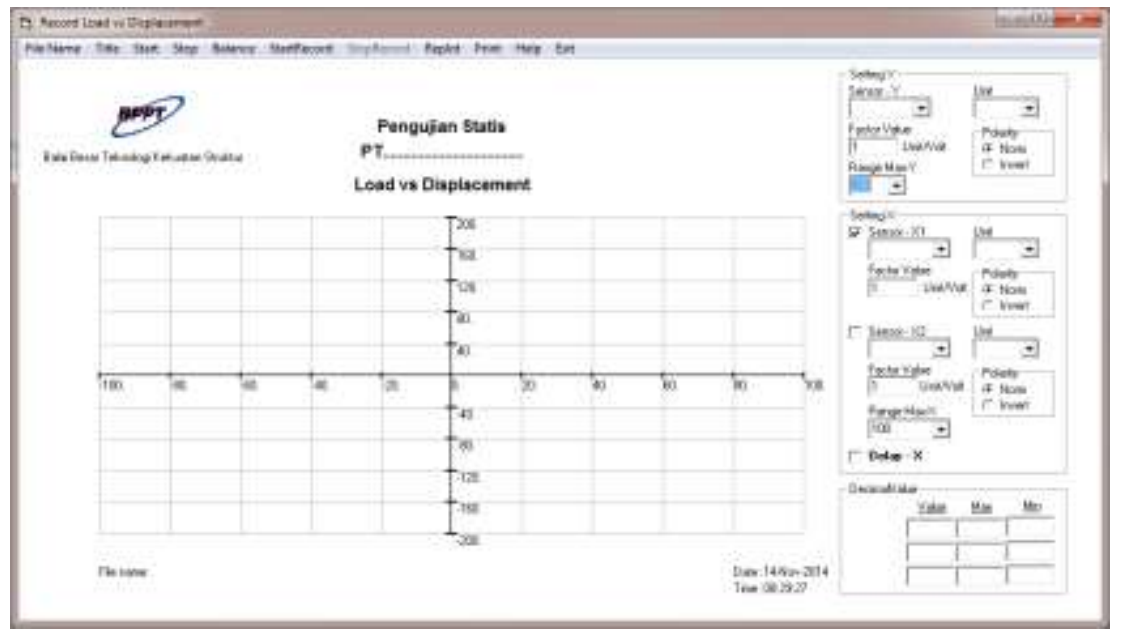

Gambar 6 : Rancangan window XY Recorder

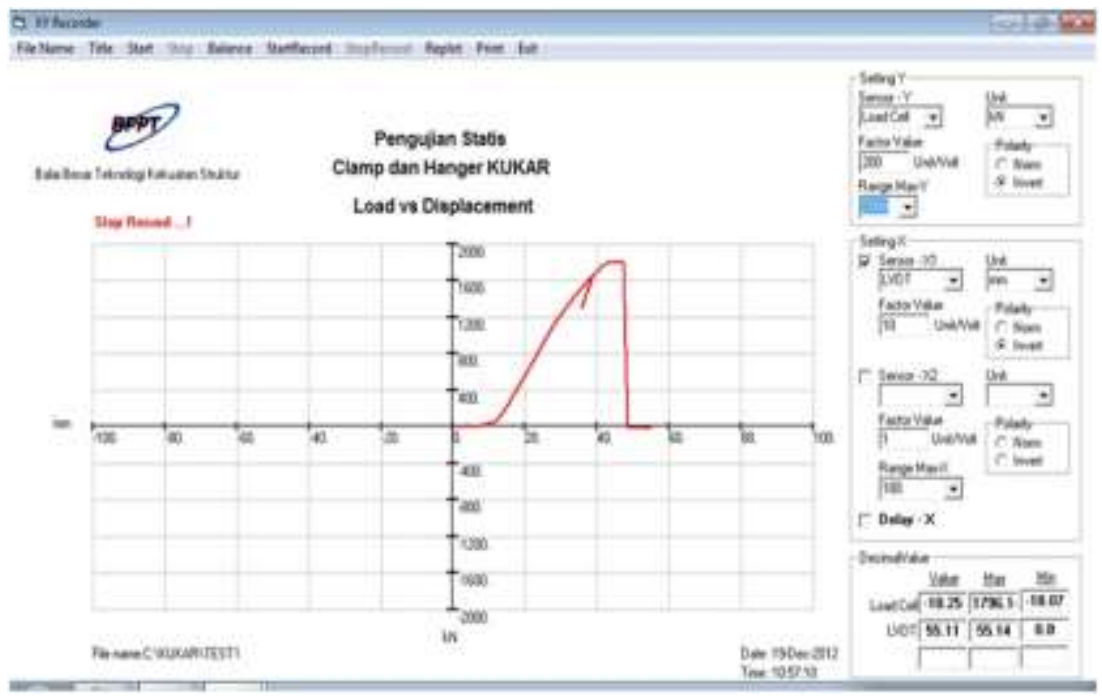

Gambar 7 : Setting Window XY Recorder pada saat pengujian

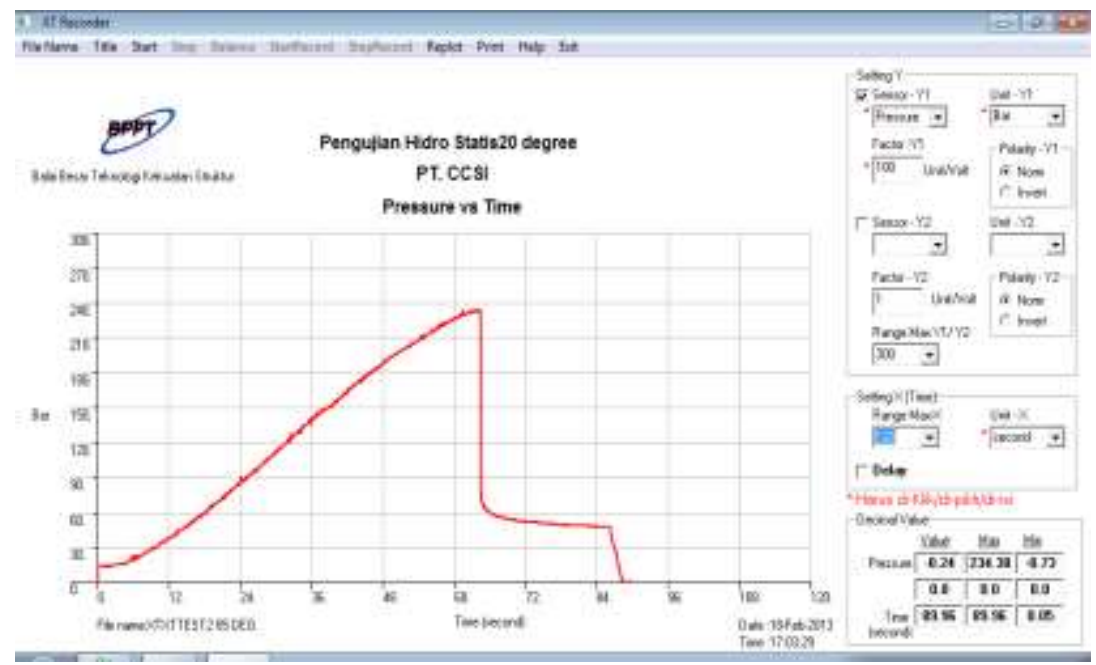

Gambar 8 : Setting Window XT Recorder pada saat pengujian 


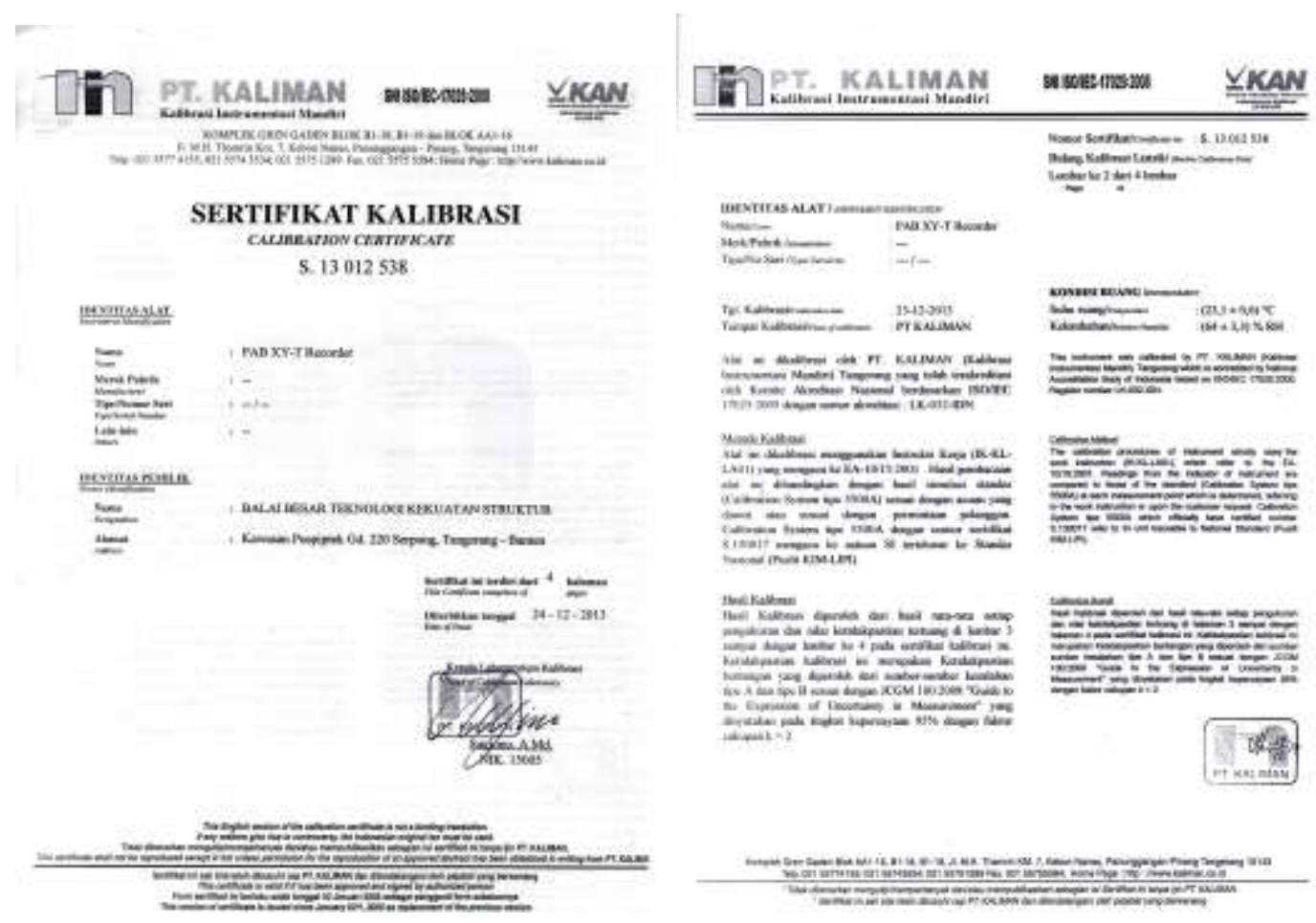

Gambar 9 : Sertifikat kalibrasi dari PT. Kaliman (hal. 1 dan 2)

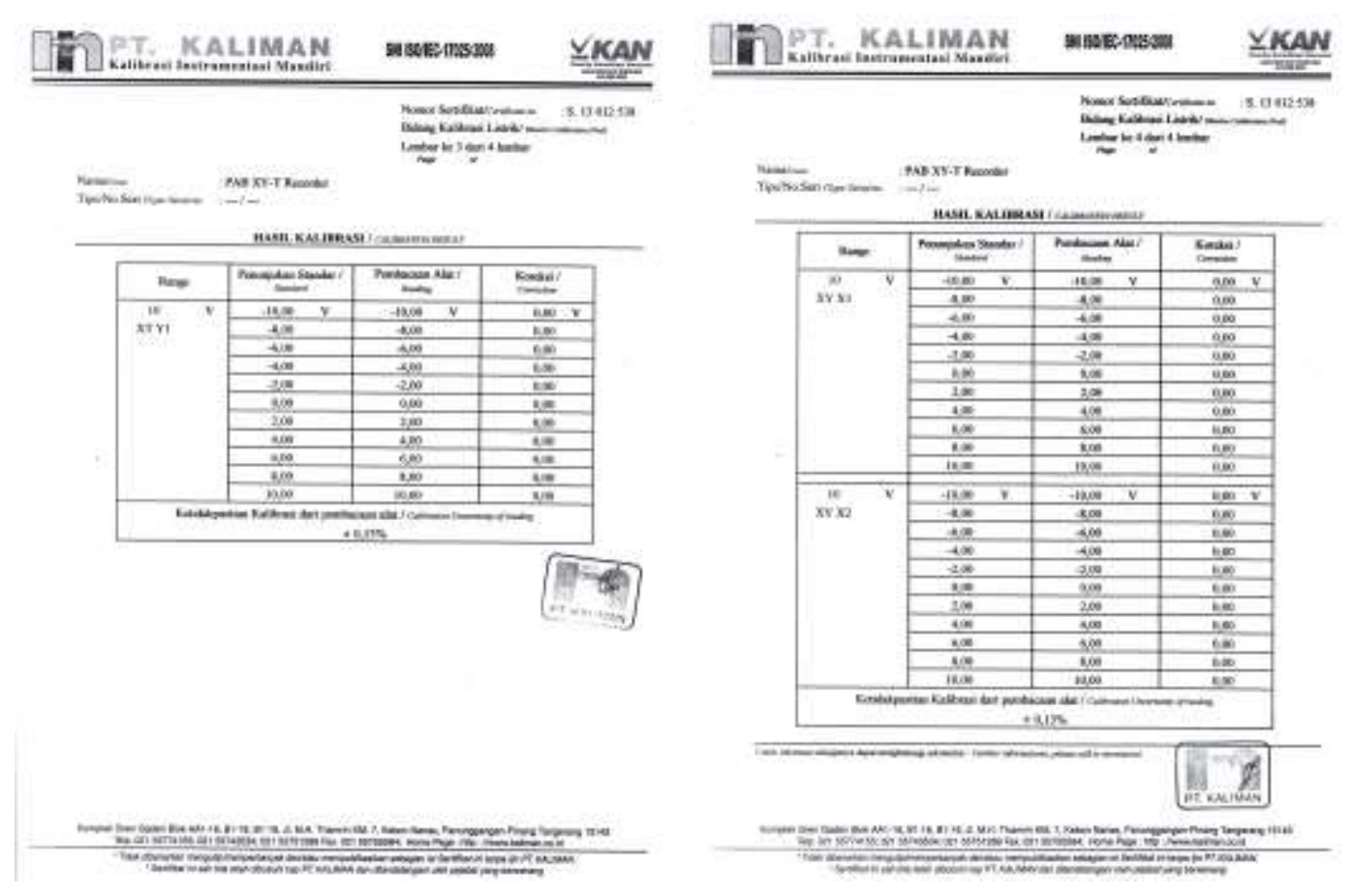

Gambar 10 : Sertifikat kalibrasi dari PT. Kaliman (hal. 3 dan 4) 


\subsubsection{Uji Coba}

Uji coba dilakukan dengan membandingkan hasil keluaran (output) antara XY-T Recorder berbasis digital hasil rancangan dengan $\mathrm{XY}$ - $\mathrm{T}$ Recorder berbasis analog yang telah dimiliki oleh B2TKS pada saat pengujian. Gambar 11 menunjukkan kegiatan pengujian hidrostatis pipa yang dilakukan di B2TKS, dimana secara bersamaan kedua alat ini digunakan untuk melakukan perekaman grafik hasil pengujian. Gambar 11 (a) menunjukkan hasil keluaran XY-T Recorder berbasis digital dan 11 (b) menunjukkan hasil keluaran XY-T Recorder berbasis analog, dari kedua hasil keluaran tersebut menunjukkan hasil yang sama.

Gambar 12 menunjukkan kegiatan pengujian statis di mesin $\mathrm{RHZ}$ yang dilakukan di B2TKS, dimana secara bersamaan kedua alat ini digunakan untuk melakukan perekaman grafik hasil pengujian. Gambar 12 (a) menunjukkan hasil keluaran XY-T Recorder berbasis digital dan 12 (b) menunjukkan hasil keluaran XY-T Recorder berbasis analog, dari kedua hasil keluaran tersebut menunjukkan hasil yang sama.
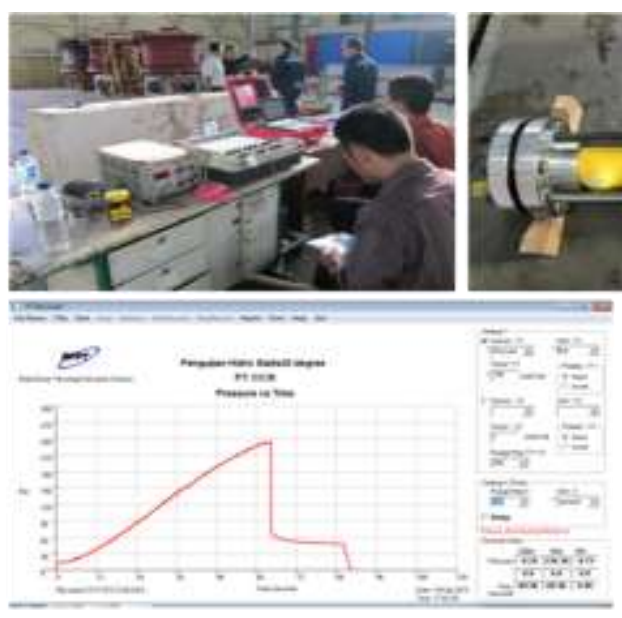

(a).
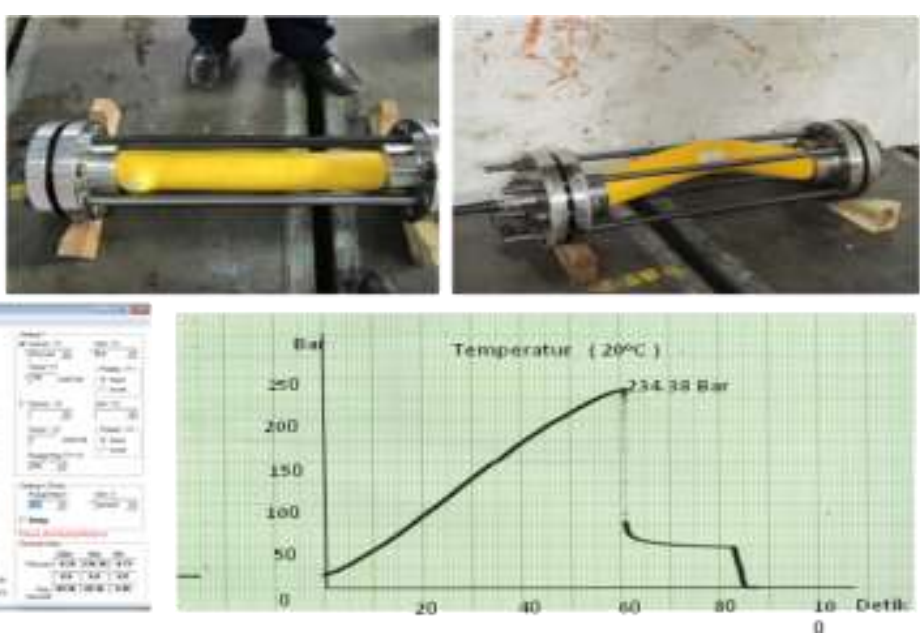

(b).

Gambar 11 : Kegiatan pengujian hidrostatis pipa dan grafik hasil pengujian hidrostatis pipa (a) keluaran XY-T Recorder berbasis digital, (b) XY-T Recorder berbasis analog.

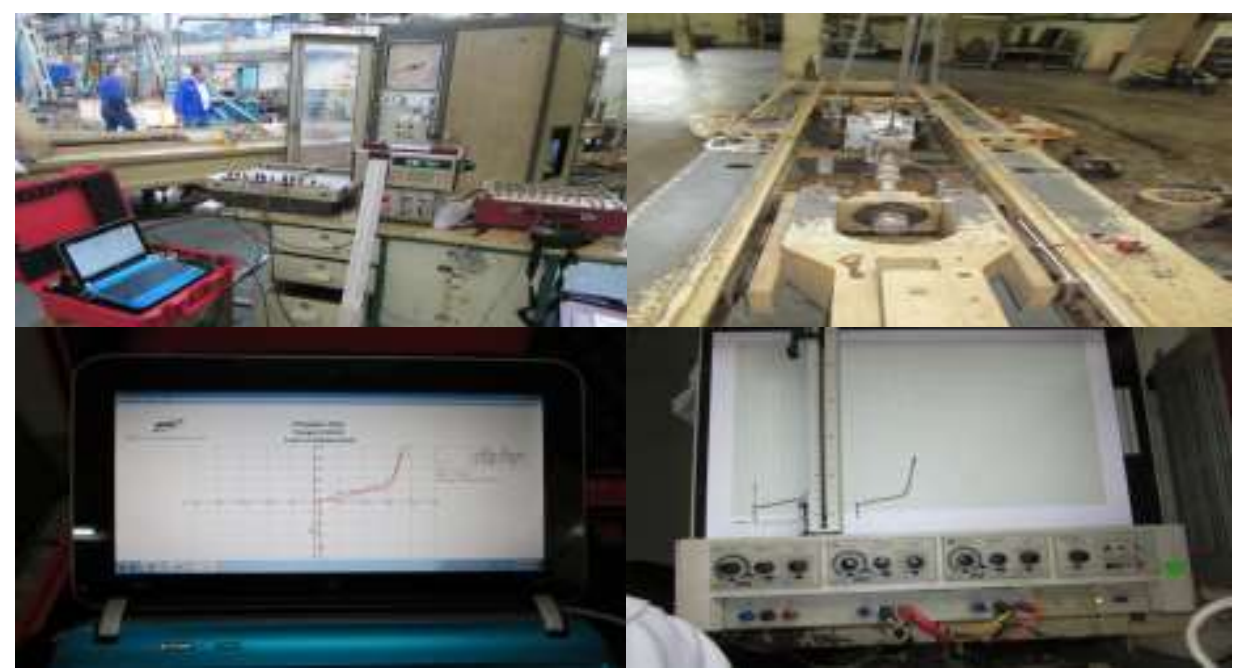

(a).

(b).

Gambar 12 : Kegiatan pengujian statis dan grafik hasil pengujian statis Clamp dan Hanger Jembatan KUKAR

(a). keluaran XY-T Recorder berbasis digital,

(b). XY-T Recorder berbasis analog. 


\section{KESIMPULAN}

Dari hasil uraian dan penjelasan diatas, maka dapat disimpulkan bahwa ; hasil kalibrasi XY-T Recorder digital oleh PT. Kaliman, menunjukkan ketidakpastian kalibrasi sebesar $0,13 \%$ pada tingkat kepercayaan $95 \%$ dengan faktor $k=2$, hal ini menunjukkan ketelitian yang cukup bagus. Hasil uji coba XY-T Recorder digital yang dilakukan pada saat pengujian, relatip sama dengan XY-T Recorder analog yang telah dimiliki B2TKS, hal ini bisa dilihat dari pola dan nilai besarannya dan XY-T Recorder digital cukup mudah untuk dioperasikan.

\section{DAFTAR PUSTAKA}

1. ISO/IEC 17025:2005, "General Requirements for the Competence of Testing and Calibration Laboratories", ISO, 2014.

2. Adi Kurniadi, "Pemrograman Microsoft Visual Basic 6",PT. Elex Media Komputindo, Jakarta, 2003.
3. Wiryanto Dewobroto, "Aplikasi Sain dan Teknik dengan Visual Basic 6.0", PT. Elex Media Komputindo, Jakarta, 2010.

4. Morris, Alan S., "Measurement and Instrumentation Principles", Butterworth Heinemann, 2009,.

5. PUSLIT KIM-LIPI, "Ketidakpastian Pengkuran”, Bahan Pelatihan, PUSLIT KIM-LIPI, 2009.

6. Advantech Co., Ltd., "USB-4704 User Manual”, Advantech Co., Ltd., 2010.

7. Pelgrom, Marcel J. M.,"Analog-toDigital Conversion",Springer eBooks, 2013.

8. Glenford J.Myers, Corey Sandler, Tom Badgett, "The Art of Software Testing”, Wiley Publisher, 2011.

9. U.A.Bakshi,A.V.Bakshi, "Fundamentals of Instrumentation", Technical Publication, 2009.

10. Dr.J.S.Chitode, “ Digital communication”, Technical Publication, 2009. 
M.I. Mat. Konst. Vol. 14 No: 2 Desember 2014 : 35 - 43 